\title{
6. ABORIGINAL AND TORRES STRAIT ISLANDER MOTHERS AND BABIES
}

\section{Reporting of Aboriginality}

Maternal Aboriginality is under-reported on the MDC. One method of assessing the extent of under-reporting and monitoring changes over time is to compare the reporting of maternal Aboriginality to the MDC with reporting of maternal Aboriginality on birth registrations held by the NSW Registry of Births, Deaths and Marriages. Using capture-recapture methods, an estimate of the total number of babies born to Aboriginal mothers was obtained and compared with the number of babies born to Aboriginal mothers as reported to the MDC. The method used here is described in Chapter 3 (page 13).
The percentage of births to Aboriginal and Torres Strait Islander mothers reported to the MDC ranged from 65 to 70 per cent between 2000 and 2003. Reporting varied markedly between area health services, ranging from 37.5 per cent in the Sydney South West Area to 89.4 per cent in the Greater Western Area in 2003 (Table 34, Figure 2).

Under-reporting of Aboriginality on the MDC means that numbers of births presented in this chapter should be interpreted with caution. The total number of babies born to Aboriginal mothers in 2003 is estimated to be 3,282, about one and a half times higher than the number reported to the MDC.

\section{TABLE 34}

BIRTHS TO ABORIGINAL AND TORRES STRAIT ISLANDER MOTHERS BY SOURCE OF BIRTH REPORT, YEAR OF BIRTH AND HEALTH AREA OF HOSPITAL, NSW 2000-2003"

\begin{tabular}{|c|c|c|c|c|c|c|}
\hline $\begin{array}{l}\text { Year- } \\
\text { Area health service } \\
\text { of hospital }\end{array}$ & $\begin{array}{c}\text { MDC } \\
\text { births }\end{array}$ & $\begin{array}{l}\text { RBDM } \\
\text { births }\end{array}$ & $\begin{array}{l}\text { Births } \\
\text { reported } \\
\text { to both } \\
\text { MDC-RBDM } \\
\text { No. }\end{array}$ & $\begin{array}{l}\text { Total } \\
\text { estimated } \\
\text { Aboriginal } \\
\text { births } \\
\text { No. }\end{array}$ & $\begin{array}{c}\text { Estimated } \\
\text { Aboriginal } \\
\text { births } \\
\text { reported to MDC } \\
\%\end{array}$ & $\begin{array}{l}95 \% \text { confidence } \\
\text { interval of } \\
\text { estimated births } \\
\text { reported }\end{array}$ \\
\hline \multicolumn{7}{|l|}{2000} \\
\hline Sydney South West & 185 & 287 & 137 & 387 & 47.8 & $42.8-52.8$ \\
\hline South Eastern Sydney \& Illawarra & 169 & 206 & 112 & 310 & 54.4 & $48.9-60.0$ \\
\hline Sydney West & 224 & 279 & 155 & 403 & 55.6 & $50.8-60.5$ \\
\hline Northern Sydney \& Central Coast & 84 & 94 & 48 & 164 & 51.3 & $43.6-58.9$ \\
\hline Hunter \& New England & 481 & 433 & 329 & 633 & 76.0 & $72.7-79.3$ \\
\hline North Coast & 335 & 217 & 177 & 411 & 81.6 & $77.9-85.4$ \\
\hline Greater Southern & 195 & 145 & 118 & 239 & 81.4 & $76.5-86.4$ \\
\hline Greater Western & 449 & 330 & 279 & 531 & 84.6 & $81.5-87.6$ \\
\hline NSW & 2122 & 1991 & 1355 & 3118 & 68.1 & $66.4-69.7$ \\
\hline \multicolumn{7}{|l|}{2001} \\
\hline Sydney South West & 192 & 272 & 138 & 378 & 50.8 & $45.7-55.8$ \\
\hline South Eastern Sydney \& Illawarra & 156 & 182 & 100 & 283 & 55.0 & $49.2-60.8$ \\
\hline Sydney West & 223 & 253 & 148 & 381 & 58.6 & $53.6-63.5$ \\
\hline Northern Sydney \& Central Coast & 75 & 97 & 52 & 140 & 53.8 & $45.5-62.0$ \\
\hline Hunter \& New England & 486 & 434 & 339 & 622 & 78.1 & $74.9-81.4$ \\
\hline North Coast & 336 & 197 & 162 & 408 & 82.3 & $78.6-86.0$ \\
\hline Greater Southern & 178 & 140 & 101 & 246 & 72.2 & $66.6-77.8$ \\
\hline Greater Western & 490 & 321 & 278 & 566 & 86.6 & $83.8-89.4$ \\
\hline NSW & 2136 & 1896 & 1318 & 3072 & 69.5 & $67.9-71.1$ \\
\hline \multicolumn{7}{|l|}{2002} \\
\hline Sydney South West & 166 & 269 & 113 & 395 & 42.1 & $37.2-46.9$ \\
\hline South Eastern Sydney \& IIlawarra & 179 & 203 & 106 & 342 & 52.3 & $47.0-57.6$ \\
\hline Sydney West & 224 & 299 & 142 & 471 & 47.6 & $43.0-52.1$ \\
\hline Northern Sydney \& Central Coast & 89 & 105 & 56 & 166 & 53.5 & $45.9-61.1$ \\
\hline Hunter \& New England & 534 & 421 & 317 & 709 & 75.3 & $72.1-78.5$ \\
\hline North Coast & 336 & 197 & 152 & 435 & 77.2 & $73.3-81.2$ \\
\hline Greater Southern & 165 & 117 & 90 & 214 & 77.0 & $71.4-82.6$ \\
\hline Greater Western & 489 & 303 & 268 & 553 & 88.5 & $85.8-91.1$ \\
\hline NSW & 2182 & 1914 & 1244 & 3357 & 65.0 & $63.4-66.6$ \\
\hline \multicolumn{7}{|l|}{2003} \\
\hline Sydney South West & 174 & 275 & 103 & 463 & 37.5 & $33.1-42.0$ \\
\hline South Eastern Sydney \& Illawarra & 180 & 180 & 111 & 292 & 61.7 & $56.2-67.3$ \\
\hline Sydney West & 242 & 276 & 140 & 476 & 50.8 & $46.3-55.3$ \\
\hline Northern Sydney \& Central Coast & 82 & 110 & 56 & 161 & 51.0 & $43.3-58.8$ \\
\hline Hunter \& New England & 535 & 426 & 336 & 678 & 78.9 & $75.8-82.0$ \\
\hline North Coast & 319 & 181 & 142 & 406 & 78.5 & $74.5-82.5$ \\
\hline Greater Southern & 176 & 115 & 89 & 227 & 77.5 & $72.1-82.9$ \\
\hline Greater Western & 482 & 291 & 260 & 539 & 89.4 & $86.8-92.0$ \\
\hline NSW & 2190 & 1854 & 1237 & 3282 & 66.7 & $65.1-68.3$ \\
\hline
\end{tabular}




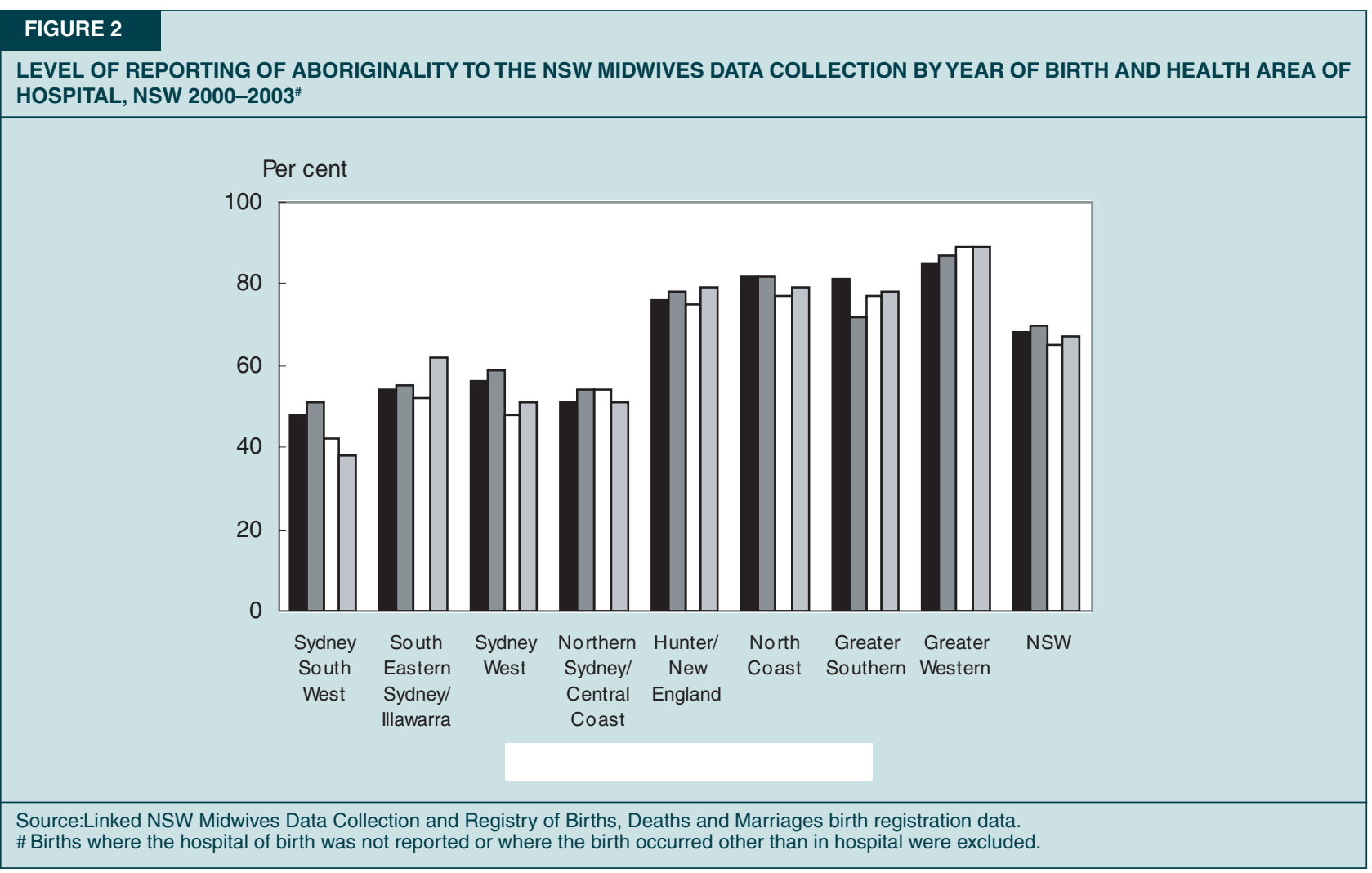

Information on paternal Aboriginality is not collected by the MDC, but is reported to the NSW Registry of Births, Deaths and Marriages. Of the 85,946 births registered for residents of NSW in 2003, 3,253 (3.8 per cent) were reported to have an Aboriginal or Torres Strait Islander mother or father (Table 35). For 1,177 babies, the mother was reported to be non-Aboriginal or Torres Strait Islander and the father was reported to be Aboriginal or Torres Strait Islander. There are therefore a substantial number of babies with non-indigenous mothers and indigenous fathers who are not represented in the numbers reported in this chapter.

\section{TABLE 35}

BIRTH REGISTRATIONS BY MATERNAL AND PATERNAL INDIGENOUS STATUS, NSW 2003"

\begin{tabular}{|c|c|c|c|}
\hline Mother\# & Father & No. & $\%$ \\
\hline Aboriginal or Torres Strait Islander & Aboriginal or Torres Strait Islander & 678 & 0.8 \\
\hline Aboriginal or Torres Strait Islander & Non-Aboriginal or Torres Strait Islander & 1398 & 1.6 \\
\hline Non-Aboriginal or Torres Strait Islander & Aboriginal or Torres Strait Islander & 1177 & 1.4 \\
\hline Non-Aboriginal or Torres Strait Islander & Non-Aboriginal or Torres Strait Islander & 82693 & 96.2 \\
\hline TOTAL & TOTAL & 85946 & 100.0 \\
\hline
\end{tabular}

Source: Australian Bureau of Statistics birth registration data (HOIST), Centre for Epidemiology and Research, NSW Department of Health. \# Births registered among NSW residents. Births where indigenous status was not stated were classified as non-Aboriginal or Torres Strait Islander. 


\section{Trends in births}

In 2004, 2,184 babies were born to Aboriginal mothers, 48 babies were born to Torres Strait Islander mothers and 101 babies were born to mothers of both Aboriginal and Torres Strait Islander background (Table 36).

\begin{tabular}{|c|c|c|c|c|c|c|c|c|c|c|}
\hline \multirow[t]{3}{*}{ Plurality } & \multirow{2}{*}{\multicolumn{2}{|c|}{2000}} & \multirow{2}{*}{\multicolumn{2}{|c|}{2001}} & \multirow{2}{*}{\multicolumn{2}{|c|}{$\begin{array}{l}\text { Year } \\
2002\end{array}$}} & \multirow{2}{*}{\multicolumn{2}{|c|}{2003}} & \multirow{2}{*}{\multicolumn{2}{|c|}{2004}} \\
\hline & & & & & & & & & & \\
\hline & No. & $\%$ & No. & $\%$ & No. & $\%$ & No. & $\%$ & No. & $\%$ \\
\hline \multicolumn{11}{|l|}{ Pregnancies } \\
\hline Aboriginal & 1990 & 94.5 & 1988 & 94.2 & 2041 & 94.7 & 2014 & 93.2 & 2161 & 93.6 \\
\hline Torres Strait Islander & 25 & 1.2 & 40 & 1.9 & 25 & 1.2 & 35 & 1.6 & 48 & 2.1 \\
\hline Both Aboriginal and TSI & 90 & 4.3 & 82 & 3.9 & 89 & 4.1 & 112 & 5.2 & 99 & 4.3 \\
\hline TOTAL & 2105 & 100.0 & 2110 & 100.0 & 2155 & 100.0 & 2161 & 100.0 & 2308 & 100.0 \\
\hline \multicolumn{11}{|l|}{ Births } \\
\hline Aboriginal & 2006 & 94.5 & 2014 & 94.2 & 2069 & 94.8 & 2039 & 93.1 & 2184 & 93.6 \\
\hline Torres Strait Islander & 25 & 1.2 & 42 & 2.0 & 25 & 1.1 & 37 & 1.7 & 48 & 2.1 \\
\hline Both Aboriginal and TSI & 91 & 4.3 & 82 & 3.8 & 89 & 4.1 & 114 & 5.2 & 101 & 4.3 \\
\hline TOTAL & 2122 & 100.0 & 2138 & 100.0 & 2183 & 100.0 & 2190 & 100.0 & 2333 & 100.0 \\
\hline
\end{tabular}

\section{Plurality}

Between 2000 and 2004, the reported number of babies born to Aboriginal and Torres Strait Islander mothers increased from 2,122 to 2,333 (Table 37), representing 2.4 and 2.7 per cent respectively of all babies born in NSW. Multiple pregnancies (twins, triplets etc.) were reported for about one per cent of mothers.

\section{TABLE 37}

ABORIGINAL AND TORRES STRAIT ISLANDER MOTHERS AND BABIES BY PLURALITY, NSW 2000-2004*

\begin{tabular}{|c|c|c|c|c|c|c|c|c|c|c|}
\hline \multirow[t]{2}{*}{ Plurality } & \multicolumn{2}{|c|}{2000} & & & \multicolumn{2}{|c|}{$\begin{array}{l}\text { Year } \\
2002\end{array}$} & \multicolumn{2}{|c|}{2003} & \multicolumn{2}{|c|}{2004} \\
\hline & No. & $\%$ & No. & $\%$ & No. & $\%$ & No. & $\%$ & No. & $\%$ \\
\hline \multicolumn{11}{|c|}{ Pregnancies } \\
\hline Singleton & 2089 & 99.2 & 2082 & 98.7 & 2127 & 98.7 & 2134 & 98.8 & 2283 & 98.9 \\
\hline Twins & 16 & 0.8 & 28 & 1.3 & 28 & 1.3 & 26 & 1.2 & 25 & 1.1 \\
\hline Triplets & 0 & 0.0 & 0 & 0.0 & 0 & 0.0 & 1 & 0.0 & 0 & 0.0 \\
\hline TOTAL & 2105 & 100.0 & 2110 & 100.0 & 2155 & 100.0 & 2161 & 100.0 & 2308 & 100.0 \\
\hline \multicolumn{11}{|l|}{ Births } \\
\hline Singleton & 2089 & 98.4 & 2082 & 97.4 & 2127 & 97.4 & 2134 & 97.4 & 2283 & 97.9 \\
\hline Twins & 33 & 1.6 & 56 & 2.6 & 56 & 2.6 & 53 & 2.4 & 50 & 2.1 \\
\hline Triplets & 0 & 0.0 & 0 & 0.0 & 0 & 0.0 & 3 & 0.1 & 0 & 0.0 \\
\hline TOTAL & 2122 & 100.0 & 2138 & 100.0 & 2183 & 100.0 & 2190 & 100.0 & 2333 & 100.0 \\
\hline
\end{tabular}

Source: NSW Midwives Data Collection (HOIST). Centre for Epidemiology and Research, NSW Department of Health.

\# Due to under-reporting of Aboriginality to the MDC, it is likely that the true numbers are about one and a half times higher than shown. 


\section{Previous pregnancies}

In 2004, one-third of Aboriginal and Torres Strait Islander mothers gave birth for the first time (Table 38). About 58 per cent of mothers reported between one and 4 previous births and 9.6 per cent of mothers had given birth to 5 or more babies. This pattern has not changed substantially since 2000.

\section{TABLE 38}

NUMBER OF PREVIOUS PREGNANCIES AMONG ABORIGINAL AND TORRES STRAIT ISLANDER MOTHERS, NSW 2000-2004"

\begin{tabular}{|c|c|c|c|c|c|c|c|c|c|c|}
\hline \multirow[t]{2}{*}{$\begin{array}{l}\text { No. previous } \\
\text { pregnancies (>20 weeks) }\end{array}$} & \multicolumn{2}{|c|}{2000} & \multicolumn{2}{|c|}{2001} & \multicolumn{2}{|c|}{$\begin{array}{l}\text { Year } \\
2002\end{array}$} & \multicolumn{2}{|c|}{2003} & \multicolumn{2}{|c|}{2004} \\
\hline & No. & $\%$ & No. & $\%$ & No. & $\%$ & No. & $\%$ & No. & $\%$ \\
\hline 0 & 645 & 30.6 & 634 & 30.0 & 664 & 30.8 & 668 & 30.9 & 759 & 32.9 \\
\hline $1-4$ & 1285 & 61.0 & 1309 & 62.0 & 1302 & 60.4 & 1316 & 60.9 & 1327 & 57.5 \\
\hline $5+$ & 174 & 8.3 & 164 & 7.8 & 183 & 8.5 & 177 & 8.2 & 221 & 9.6 \\
\hline Not stated & 1 & 0.0 & 3 & 0.1 & 6 & 0.3 & 0 & 0.0 & 1 & 0.0 \\
\hline TOTAL & 2105 & 100.0 & 2110 & 100.0 & 2155 & 100.0 & 2161 & 100.0 & 2308 & 100.0 \\
\hline
\end{tabular}

Source: NSW Midwives Data Collection (HOIST). Centre for Epidemiology and Research, NSW Department of Health.

\# Due to under-reporting of Aboriginality to the MDC, it is likely that the true numbers are about one and a half times higher than shown.

\section{Maternal age}

The reported number of babies born to Aboriginal and Torres Strait Islander mothers has increased at all ages. About one in 5 Aboriginal and Torres Strait Islander mothers were teenagers in 2004.

Following statewide trends, the number of mothers giving birth at 35 years of age or more has increased over the last 5 years. The proportion of mothers aged 35-plus years increased from 7.4 per cent in 2000 to 9.6 per cent in 2004 (Table 39).

\section{TABLE 39}

AGE OF ABORIGINAL AND TORRES STRAIT ISLANDER MOTHERS, NSW 2000-2004\#

\begin{tabular}{|c|c|c|c|c|c|c|c|c|c|c|}
\hline \multirow[t]{2}{*}{$\begin{array}{l}\text { Maternal age } \\
\text { (years) }\end{array}$} & \multicolumn{2}{|c|}{2000} & \multicolumn{2}{|c|}{2001} & \multicolumn{2}{|c|}{$\begin{array}{l}\text { Year } \\
2002\end{array}$} & \multicolumn{2}{|c|}{2003} & \multicolumn{2}{|c|}{2004} \\
\hline & No. & $\%$ & No. & $\%$ & No. & $\%$ & No. & $\%$ & No. & $\%$ \\
\hline $12-19$ & 459 & 21.8 & 439 & 20.8 & 481 & 22.3 & 455 & 21.1 & 493 & 21.4 \\
\hline 20-34 & 1491 & 70.8 & 1515 & 71.8 & 1524 & 70.7 & 1553 & 71.9 & 1594 & 69.1 \\
\hline $35+$ & 155 & 7.4 & 152 & 7.2 & 146 & 6.8 & 153 & 7.1 & 221 & 9.6 \\
\hline Not stated & 0 & 0.0 & 4 & 0.2 & 4 & 0.2 & 0 & 0.0 & 0 & 0.0 \\
\hline TOTAL & 2105 & 100.0 & 2110 & 100.0 & 2155 & 100.0 & 2161 & 100.0 & 2308 & 100.0 \\
\hline
\end{tabular}

Source: NSW Midwives Data Collection (HOIST). Centre for Epidemiology and Research, NSW Department of Health.

\# Due to under-reporting of Aboriginality to the MDC, it is likely that the true numbers are about one and a half times higher than shown. 


\section{Health area of residence}

The reported number of Aboriginal and Torres Strait Islander mothers who gave birth in 2004 ranged from 93 in the Northern Sydney and Central Coast Area to 508 in the Greater Western Area (Table 40). The proportion of mothers who were teenagers varied from 11.8 per cent in the Northern Sydney and Central Coast Area to 26.9 per cent in the Sydney West Area (Table 41).

\begin{tabular}{|c|c|c|c|c|c|c|c|c|c|c|}
\hline \multirow[t]{2}{*}{ Health Area } & \multicolumn{2}{|c|}{2000} & \multicolumn{2}{|c|}{2001} & \multicolumn{2}{|c|}{$\begin{array}{l}\text { Year } \\
2002\end{array}$} & \multicolumn{2}{|c|}{2003} & \multicolumn{2}{|c|}{2004} \\
\hline & No. & $\%$ & No. & $\%$ & No. & $\%$ & No. & $\%$ & No. & $\%$ \\
\hline Sydney South West & 168 & 8.0 & 174 & 8.2 & 165 & 7.7 & 160 & 7.4 & 164 & 7.1 \\
\hline \multicolumn{11}{|l|}{ South Eastern Sydney \& } \\
\hline Illawarra & 173 & 8.2 & 153 & 7.3 & 173 & 8.0 & 178 & 8.2 & 221 & 9.6 \\
\hline Sydney West & 203 & 9.6 & 213 & 10.1 & 204 & 9.5 & 237 & 11.0 & 238 & 10.3 \\
\hline \multicolumn{11}{|l|}{ Northern Sydney \& } \\
\hline Central Coast & 81 & 3.8 & 74 & 3.5 & 85 & 3.9 & 82 & 3.8 & 93 & 4.0 \\
\hline Hunter \& New England & 474 & 22.5 & 477 & 22.6 & 513 & 23.8 & 514 & 23.8 & 508 & 22.0 \\
\hline North Coast & 330 & 15.7 & 329 & 15.6 & 327 & 15.2 & 304 & 14.1 & 390 & 16.9 \\
\hline Greater Southern & 176 & 8.4 & 162 & 7.7 & 158 & 7.3 & 170 & 7.9 & 173 & 7.5 \\
\hline Greater Western & 484 & 23.0 & 511 & 24.2 & 517 & 24.0 & 493 & 22.8 & 505 & 21.9 \\
\hline Other-Not stated & 16 & 0.8 & 17 & 0.8 & 13 & 0.6 & 23 & 1.1 & 16 & 0.7 \\
\hline TOTAL & 2105 & 100.0 & 2110 & 100.0 & 2155 & 100.0 & 2161 & 100.0 & 2308 & 100.0 \\
\hline
\end{tabular}

\section{TABLE 41}

HEALTH AREA OF RESIDENCE OF ABORIGINAL AND TORRES STRAIT ISLANDER MOTHERS BY AGE, NSW 2004"

Health Area $\quad$ Less than 20 Maternal age (years)

\begin{tabular}{|c|c|c|c|c|c|c|}
\hline \multirow[t]{2}{*}{ 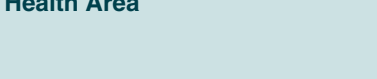 } & & \multicolumn{2}{|c|}{ TOTAL } \\
\hline & No. & $\%$ & No. & $\%$ & No. & $\%$ \\
\hline Sydney South West & 33 & 20.1 & 131 & 79.9 & 164 & 100.0 \\
\hline South Eastern Sydney \& IIlawarra & 38 & 17.2 & 183 & 82.8 & 221 & 100.0 \\
\hline Sydney West & 64 & 26.9 & 174 & 73.1 & 238 & 100.0 \\
\hline Northern Sydney \& Central Coast & 11 & 11.8 & 82 & 88.2 & 93 & 100.0 \\
\hline Hunter \& New England & 115 & 22.6 & 393 & 77.4 & 508 & 100.0 \\
\hline North Coast & 70 & 17.9 & 320 & 82.1 & 390 & 100.0 \\
\hline Greater Southern & 37 & 21.4 & 136 & 78.6 & 173 & 100.0 \\
\hline Greater Western & 120 & 23.8 & 385 & 76.2 & 505 & 100.0 \\
\hline Other-Not stated & 5 & 31.3 & 11 & 68.8 & 16 & 100.0 \\
\hline TOTAL & 493 & 21.4 & 1815 & 78.6 & 2308 & 100.0 \\
\hline
\end{tabular}

Source: NSW Midwives Data Collection (HOIST). Centre for Epidemiology and Research, NSW Department of Health.

\# Due to under-reporting of Aboriginality to the MDC, it is likely that the true numbers for the total are about one and a half times higher than shown.

The level of under-reporting varies between area health services (Table 34). 


\section{Booking status}

In 2004, 89.9 per cent of Aboriginal and Torres Strait Islander mothers were booked into the hospital of birth, a slight rise from 87.5 per cent in 2000. In 2004, 97.5 per cent of non-Aboriginal or Torres Strait Islander mothers were booked into the hospital of birth.

\section{Duration of pregnancy at first antenatal visit}

Between 2000 and 2004, the proportion of mothers who commenced antenatal care at less than 20 weeks gestation rose from 67.6 to 70.1 per cent (Table 42). This compares with 88.0 per cent of non-Aboriginal or Torres Strait Islander mothers who commenced antenatal care at less than 20 weeks gestation in 2004 .

In 2004, the proportion of Aboriginal and Torres Strait Islander mothers who commenced antenatal care at less than 20 weeks gestation varied from 58.0 per cent in the Sydney West Area to 81.7 per cent in the Northern Sydney \& Central Coast Area (Table 43).

\section{TABLE 42}

DURATION OF PREGNANCY AT FIRST ANTENATAL VISIT AMONG ABORIGINAL AND TORRES STRAIT ISLANDER MOTHERS, NSW 2000-2004"

\begin{tabular}{|c|c|c|c|c|c|c|c|c|c|c|}
\hline \multirow[t]{2}{*}{$\begin{array}{l}\text { Duration of pregnancy at first } \\
\text { antenatal visit (weeks) }\end{array}$} & \multicolumn{2}{|c|}{2000} & \multicolumn{2}{|c|}{2001} & \multicolumn{2}{|c|}{$\begin{array}{l}\text { Year } \\
2002\end{array}$} & \multicolumn{2}{|c|}{2003} & \multicolumn{2}{|c|}{2004} \\
\hline & No. & $\%$ & No. & $\%$ & No. & $\%$ & No. & $\%$ & No. & $\%$ \\
\hline $0-19$ & 1422 & 67.6 & 1365 & 64.7 & 1448 & 67.2 & 1526 & 70.6 & 1618 & 70.1 \\
\hline 20-plus & 546 & 25.9 & 615 & 29.1 & 560 & 26.0 & 547 & 25.3 & 573 & 24.8 \\
\hline Not stated & 137 & 6.5 & 130 & 6.2 & 147 & 6.8 & 88 & 4.1 & 117 & 5.1 \\
\hline TOTAL & 2105 & 100.0 & 2110 & 100.0 & 2155 & 100.0 & 2161 & 100.0 & 2308 & 100.0 \\
\hline
\end{tabular}

Source: NSW Midwives Data Collection (HOIST). Centre for Epidemiology and Research, NSW Department of Health.

\# Due to under-reporting of Aboriginality to the MDC, it is likely that the true numbers are about one and a half times higher than shown.

\section{TABLE 43}

DURATION OF PREGNANCY AT FIRST ANTENATAL VISIT AMONG ABORIGINAL AND TORRES STRAIT ISLANDER MOTHERS BY HEALTH AREA OF RESIDENCE, NSW 2004"

\begin{tabular}{|c|c|c|c|c|c|c|c|c|}
\hline \multirow[t]{3}{*}{ Health Area } & \multicolumn{8}{|c|}{ Duration of pregnancy at first antenatal visit (weeks) } \\
\hline & \multicolumn{2}{|c|}{$0-19$} & \multicolumn{2}{|c|}{$20+$} & \multicolumn{2}{|c|}{ Not stated } & \multicolumn{2}{|c|}{ TOTAL } \\
\hline & No. & $\%$ & No. & $\%$ & No. & $\%$ & No. & $\%$ \\
\hline Sydney South West & 97 & 59.1 & 61 & 37.2 & 6 & 3.7 & 164 & 100.0 \\
\hline South Eastern Sydney \& IIlawarra & 172 & 77.8 & 46 & 20.8 & 3 & 1.4 & 221 & 100.0 \\
\hline Sydney West & 138 & 58.0 & 90 & 37.8 & 10 & 4.2 & 238 & 100.0 \\
\hline Northern Sydney \& Central Coast & 76 & 81.7 & 15 & 16.1 & 2 & 2.2 & 93 & 100.0 \\
\hline Hunter \& New England & 345 & 67.9 & 125 & 24.6 & 38 & 7.5 & 508 & 100.0 \\
\hline North Coast & 291 & 74.6 & 73 & 18.7 & 26 & 6.7 & 390 & 100.0 \\
\hline Greater Southern & 129 & 74.6 & 39 & 22.5 & 5 & 2.9 & 173 & 100.0 \\
\hline Greater Western & 356 & 70.5 & 122 & 24.2 & 27 & 5.3 & 505 & 100.0 \\
\hline Other-Not stated & 14 & 87.5 & 2 & 12.5 & 0 & 0.0 & 16 & 100.0 \\
\hline TOTAL & 1618 & 70.1 & 573 & 24.8 & 117 & 5.1 & 2308 & 100.0 \\
\hline
\end{tabular}

Source: NSW Midwives Data Collection (HOIST). Centre for Epidemiology and Research, NSW Department of Health.

\# Due to under-reporting of Aboriginality to the MDC, it is likely that the true numbers for the total are about one and a half times higher than shown.

The level of under-reporting varies between area health services (Table 34). 


\section{Smoking in pregnancy}

In 2004, 56.6 per cent of Aboriginal and Torres Strait Islander mothers reported smoking at some time during pregnancy, compared to 55.9 per cent in 2000. This compares with 13.6 per cent of non-Aboriginal or Torres Strait Islander mothers who reported smoking at some time during pregnancy in 2004.
Smoking in the second half of pregnancy poses the greatest risk to the health of both mother and baby. In 2004, 55.2 per cent of Aboriginal and Torres Strait Islander mothers reported smoking in the second half of pregnancy. This percentage varied from 39.9 per cent in the Northern Sydney and Central Coast Area to 61.3 per cent in the Greater Southern Area (Figure 3).

\section{FIGURE 3}

SMOKING IN THE SECOND HALF OF PREGNANCY AMONG ABORIGINAL AND TORRES STRAIT ISLANDER MOTHERS BY AMOUNT SMOKED AND HEALTH AREA OF RESIDENCE, NSW 2004"

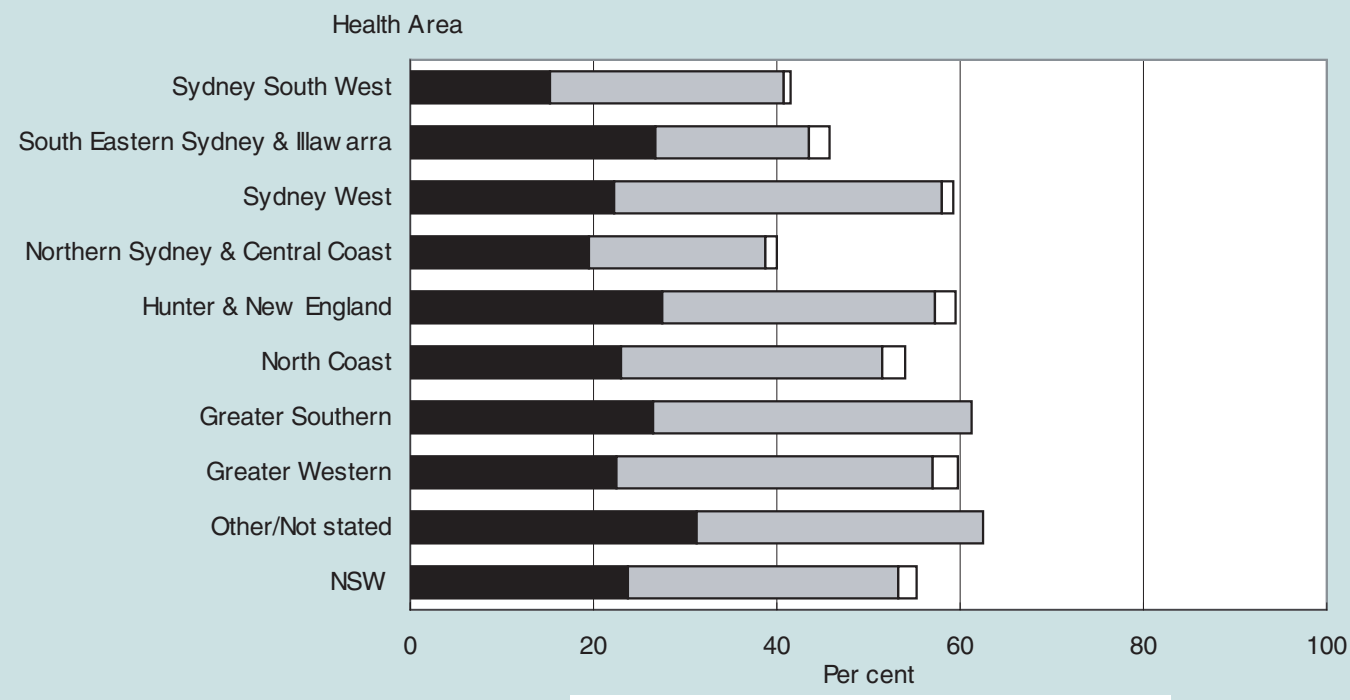

—1-10 per day $\square$ More than 10 per day $\square$ Not stated

Source: NSW Midwives Data Collection (HOIST). Centre for Epidemiology and Research, NSW Department of Health.

\# Information not shown for health areas where the number of mothers is less than five in a group. Due to under-reporting of Aboriginality to the MDC, it is likely that the true numbers are about one and a half times higher than shown.

\section{Medical conditions and obstetric complications}

In 2004, there was a slightly lower rate of gestational diabetes reported among Aboriginal and Torres Strait Islander mothers compared with non-Aboriginal or Torres Strait Islander mothers (Table 44). The number of Aboriginal and Torres Strait Islander mothers with medical conditions and obstetric complications reported to the MDC is low, even after taking into account underreporting of maternal Aboriginality. This is particularly the case for diabetes. The low numbers may be due to under-detection and/or under-reporting.

\section{TABLE 44}

MATERNAL MEDICAL CONDITIONS AND OBSTETRIC COMPLICATIONS BY ABORIGINALITY, NSW 2004"

\begin{tabular}{|c|c|c|c|c|c|c|c|c|}
\hline \multirow[t]{3}{*}{ Condition } & \multicolumn{8}{|c|}{ Aboriginality } \\
\hline & \multicolumn{2}{|c|}{$\begin{array}{l}\text { Aboriginal and } \\
\text { Torres Strait } \\
\text { Islander }\end{array}$} & \multicolumn{2}{|c|}{$\begin{array}{l}\text { Non-Aboriginal or } \\
\text { Torres Strait } \\
\text { Islander }\end{array}$} & \multicolumn{2}{|c|}{ Not stated } & \multicolumn{2}{|c|}{ TOTAL } \\
\hline & No. & $\%$ & No. & $\%$ & No. & $\%$ & No. & $\%$ \\
\hline Diabetes mellitus & 24 & 1.0 & 440 & 0.5 & 0 & 0.0 & 464 & 0.6 \\
\hline Gestational diabetes & 74 & 3.2 & 3518 & 4.3 & 0 & 0.0 & 3592 & 4.3 \\
\hline Essential hypertension & 22 & 1.0 & 918 & 1.1 & 0 & 0.0 & 940 & 1.1 \\
\hline Pre-eclampsia & 123 & 5.3 & 4483 & 5.5 & 0 & 0.0 & 4606 & 5.5 \\
\hline TOTAL & 2308 & 100.0 & 81948 & 100.0 & 32 & 100.0 & 84288 & 100.0 \\
\hline
\end{tabular}

Source: NSW Midwives Data Collection (HOIST). Centre for Epidemiology and Research, NSW Department of Health.

\# Due to under-reporting of Aboriginality to the MDC, it is likely that the true numbers are about one and a half times higher than shown. 


\section{Labour and delivery}

The rate of spontaneous onset of labour fell from 72.5 per cent in 2000 to 68.5 per cent in 2004 (Table 45). The rate of induction of labour among Aboriginal and Torres Strait Islander mothers varied from about 18 to 21 per cent between 2000 and 2004. The rate of induction of labour among Aboriginal and Torres Strait Islander mothers was lower than the rate of 24.5 per cent reported among nonAboriginal and Torres Strait Islander mothers in 2004.
Between 2000 and 2004, the rate of normal vaginal birth fell slightly from 74.7 to 71.4 per cent. The caesarean section rate rose from 18.2 to 22.1 per cent (Table 46). The rate of forceps delivery remained stable at about 2.5 per cent, and vaginal breech delivery fell from 1.5 to 0.7 per cent.

\section{TABLE 45}

LABOUR ONSET FOR ABORIGINAL AND TORRES STRAIT ISLANDER MOTHERS, NSW 2000-2004*

\begin{tabular}{|c|c|c|c|c|c|c|c|c|c|c|}
\hline \multirow[t]{2}{*}{ Labour onset } & \multicolumn{2}{|c|}{2000} & & & \multicolumn{2}{|c|}{$\begin{array}{l}\text { Year } \\
2002\end{array}$} & \multicolumn{2}{|c|}{2003} & \multicolumn{2}{|c|}{2004} \\
\hline & No. & $\%$ & No. & $\%$ & No. & $\%$ & No. & $\%$ & No. & $\%$ \\
\hline Spontaneous & 1527 & 72.5 & 1486 & 70.4 & 1507 & 69.9 & 1469 & 68.0 & 1581 & 68.5 \\
\hline No labour\#\# & 206 & 9.8 & 207 & 9.8 & 223 & 10.3 & 250 & 11.6 & 260 & 11.3 \\
\hline Induced & 372 & 17.7 & 417 & 19.8 & 423 & 19.6 & 442 & 20.5 & 467 & 20.2 \\
\hline Not stated & 0 & 0.0 & 0 & 0.0 & 2 & 0.1 & 0 & 0.0 & 0 & 0.0 \\
\hline TOTAL & 2105 & 100.0 & 2110 & 100.0 & 2155 & 100.0 & 2161 & 100.0 & 2308 & 100.0 \\
\hline
\end{tabular}

Source: NSW Midwives Data Collection (HOIST). Centre for Epidemiology and Research, NSW Department of Health.

\# Due to under-reporting of Aboriginality to the MDC, it is likely that the true numbers are about one and a half times higher than shown.

\#\# No labour indicates elective caesarean section.

\section{TABLE 46}

TYPE OF DELIVERY AMONG ABORIGINAL AND TORRES STRAIT ISLANDER MOTHERS, NSW 2000-2004*

\begin{tabular}{|c|c|c|c|c|c|c|c|c|c|c|}
\hline \multirow[t]{3}{*}{ Type of delivery } & \multirow{2}{*}{\multicolumn{2}{|c|}{2000}} & \multirow{2}{*}{\multicolumn{2}{|c|}{2001}} & \multirow{2}{*}{\multicolumn{2}{|c|}{$\begin{array}{l}\text { Year } \\
2002\end{array}$}} & \multirow{2}{*}{\multicolumn{2}{|c|}{2003}} & \multirow{2}{*}{\multicolumn{2}{|c|}{2004}} \\
\hline & & & & & & & & & & \\
\hline & No. & $\%$ & No. & $\%$ & No. & $\%$ & No. & $\%$ & No. & $\%$ \\
\hline Normal vaginal & 1573 & 74.7 & 1562 & 74.0 & 1598 & 74.2 & 1585 & 73.3 & 1647 & 71.4 \\
\hline Forceps & 51 & 2.4 & 39 & 1.8 & 30 & 1.4 & 35 & 1.6 & 60 & 2.6 \\
\hline Vacuum extraction & 67 & 3.2 & 66 & 3.1 & 68 & 3.2 & 67 & 3.1 & 74 & 3.2 \\
\hline Vaginal breech & 31 & 1.5 & 16 & 0.8 & 14 & 0.6 & 9 & 0.4 & 16 & 0.7 \\
\hline Elective caesarean section & 206 & 9.8 & 207 & 9.8 & 223 & 10.3 & 250 & 11.6 & 260 & 11.3 \\
\hline Emergency caesarean section $\#$ & 177 & 8.4 & 220 & 10.4 & 222 & 10.3 & 215 & 9.9 & 251 & 10.9 \\
\hline TOTAL & 2105 & 100.0 & 2110 & 100.0 & 2155 & 100.0 & 2161 & 100.0 & 2308 & 100.0 \\
\hline
\end{tabular}

Source:NSW Midwives Data Collection (HOIST). Centre for Epidemiology and Research, NSW Department of Health.

\# Due to under-reporting of Aboriginality to the MDC, it is likely that the true numbers are about one and a half times higher than shown.

\#\# Emergency caesarean section includes caesarean section where the onset of labour was not stated. 


\section{Birth weight}

Since 2000, the rate of low birth weight (less than 2,500 grams) in Aboriginal and Torres Strait Islander babies has been over 10 per cent and was 12.9 per cent in 2004 (Table 47). This is over twice the rate for babies born to non-Aboriginal or Torres Strait Islander mothers, which was 6.2 per cent in 2004. In 2004, the largest number of low birth weight babies were born in the Hunter and New England Area (Table 48).

\begin{tabular}{|c|c|c|c|c|c|c|c|c|c|c|}
\hline \multirow[t]{2}{*}{$\begin{array}{l}\text { Birth weight } \\
\text { (grams) }\end{array}$} & \multicolumn{2}{|c|}{2000} & \multicolumn{2}{|c|}{2001} & \multicolumn{2}{|c|}{$\begin{array}{l}\text { Year } \\
2002\end{array}$} & \multicolumn{2}{|c|}{2003} & \multicolumn{2}{|c|}{2004} \\
\hline & No. & $\%$ & No. & $\%$ & No. & $\%$ & No. & $\%$ & No. & $\%$ \\
\hline Less than 1,000 & 33 & 1.6 & 27 & 1.3 & 21 & 1.0 & 31 & 1.4 & 23 & 1.0 \\
\hline $1,000-1,499$ & 20 & 0.9 & 33 & 1.5 & 28 & 1.3 & 19 & 0.9 & 34 & 1.5 \\
\hline $1,500-2,499$ & 199 & 9.4 & 228 & 10.7 & 230 & 10.5 & 221 & 10.1 & 244 & 10.5 \\
\hline $2,500+$ & 1866 & 87.9 & 1848 & 86.4 & 1900 & 87.0 & 1917 & 87.5 & 2032 & 87.1 \\
\hline Not stated & 4 & 0.2 & 2 & 0.1 & 4 & 0.2 & 2 & 0.1 & 0 & 0.0 \\
\hline TOTAL & 2122 & 100.0 & 2138 & 100.0 & 2183 & 100.0 & 2190 & 100.0 & 2333 & 100.0 \\
\hline
\end{tabular}

\section{TABLE 48}

WEIGHT OF ABORIGINAL AND TORRES STRAIT ISLANDER BABIES BY HEALTH AREA OF RESIDENCE, NSW 2004"

\begin{tabular}{|c|c|c|c|c|c|c|}
\hline \multirow[t]{3}{*}{ Health Area } & \multicolumn{6}{|c|}{ Birth weight (grams) } \\
\hline & \multicolumn{2}{|c|}{ Less than 2,500} & \multicolumn{2}{|c|}{$2,500+$} & \multicolumn{2}{|c|}{ TOTAL } \\
\hline & No. & $\%$ & No. & $\%$ & No. & $\%$ \\
\hline Sydney South West & 14 & 8.5 & 150 & 91.5 & 164 & 100.0 \\
\hline South Eastern Sydney \& Illawarra & 21 & 9.4 & 203 & 90.6 & 224 & 100.0 \\
\hline Sydney West & 37 & 15.3 & 205 & 84.7 & 242 & 100.0 \\
\hline Northern Sydney \& Central Coast & 14 & 14.9 & 80 & 85.1 & 94 & 100.0 \\
\hline Hunter \& New England & 69 & 13.4 & 445 & 86.6 & 514 & 100.0 \\
\hline North Coast & 59 & 14.8 & 339 & 85.2 & 398 & 100.0 \\
\hline Greater Southern & 24 & 13.7 & 151 & 86.3 & 175 & 100.0 \\
\hline Greater Western & 62 & 12.3 & 444 & 87.7 & 506 & 100.0 \\
\hline Other-Not stated & 1 & 6.3 & 15 & 93.8 & 16 & 100.0 \\
\hline TOTAL & 301 & 12.9 & 2032 & 87.1 & 2333 & 100.0 \\
\hline
\end{tabular}

Source: NSW Midwives Data Collection (HOIST). Centre for Epidemiology and Research, NSW Department of Health.

\# Due to under-reporting of Aboriginality to the MDC, it is likely that the true numbers for the total are about one and a half times higher than shown. The level of under-reporting varies between area health services (Table 34). 


\section{Gestational age}

Since 2000, the over 10 per cent of Aboriginal and Torres Strait Islander babies have been premature (less than 37 weeks gestation) (Table 49). The rate was 11.7 per cent in 2004-compared with a rate of 7.2 per cent for babies born to non-Aboriginal or Torres Strait Islander mothers. In 2004, the largest number of premature babies were born in the Hunter and New England Area (Table 50).

\section{TABLE 49}

GESTATIONAL AGE OF ABORIGINAL AND TORRES STRAIT ISLANDER BABIES, NSW 2000-2004"

Gestational age

(weeks)

No. 2000 No. ${ }^{2001}$

$2001 \quad 2002$

$\begin{array}{llll} & \text { No. } & \text { No. } & \end{array}$

20-27

28-31

$32-36$

37-41

$42+$

Not stated

TOTAL

$\begin{array}{rrr}33 & 1.6 & 26 \\ 29 & 1.4 & 38 \\ 185 & 8.7 & 201 \\ 1839 & 86.7 & 1824 \\ 36 & 1.7 & 48 \\ 0 & 0.0 & 1 \\ 2122 & 100.0 & 2138\end{array}$

$26 \quad 1.2$

$\begin{array}{rr}38 & 1.8 \\ 201 & 9.4\end{array}$

$824 \quad 85.3$

$48 \quad 2.2$

$\begin{array}{ll}1 & 0.0\end{array}$

Source: NSW Midwives Data Collection (HOIST). Centre for Epidemiology and Research, NSW Department of Health.

\# Due to under-reporting of Aboriginality to the MDC, it is likely that the true numbers are about one and a half times higher than shown.

\section{TABLE 50}

GESTATIONAL AGE OF ABORIGINAL AND TORRES STRAIT ISLANDER BABIES BY HEALTH AREA OF RESIDENCE, NSW 2004\#

Health Area Gestational age (weeks)

\begin{tabular}{lrrrrrr} 
Health Area & \multicolumn{2}{c}{ Less than $\mathbf{3 7}$} & \multicolumn{2}{c}{ Gestational age (weeks) } \\
& No. & 37+ & No. & T & No. & TAL \\
\hline Sydney South West & 15 & 9.1 & 149 & 90.9 & 164 & 100.0 \\
South Eastern Sydney \& Illawarra & 26 & 11.6 & 198 & 88.4 & 224 & 100.0 \\
Sydney West & 26 & 10.7 & 216 & 89.3 & 242 & 100.0 \\
Northern Sydney \& Central Coast & 15 & 16.0 & 79 & 84.0 & 94 & 100.0 \\
Hunter \& New England & 64 & 12.5 & 450 & 87.5 & 514 & 100.0 \\
North Coast & 56 & 14.1 & 342 & 85.9 & 398 & 100.0 \\
Greater Southern & 23 & 13.1 & 152 & 86.9 & 175 & 100.0 \\
Greater Western & 45 & 8.9 & 461 & 91.1 & 506 & 100.0 \\
Other-Not stated & 2 & 12.5 & 14 & 87.5 & 16 & 100.0 \\
TOTAL & 272 & 11.7 & 2061 & 88.3 & 2333 & 100.0 \\
\hline
\end{tabular}

Source: NSW Midwives Data Collection (HOIST). Centre for Epidemiology and Research, NSW Department of Health.

\# Due to under-reporting of Aboriginality to the MDC, it is likely that the true numbers for the total are about one and a half times higher than shown. The level of under-reporting varies between area health services (Table 34). 


\section{Apgar score}

In 2004, 2.9 per cent of Aboriginal and Torres Strait Islander babies had an Apgar score less than seven (Table 51), higher than the rate of 2.0 per cent for babies born to non-Aboriginal or Torres Strait Islander mothers.

\section{TABLE 51}

APGAR SCORE OF ABORIGINAL AND TORRES STRAIT ISLANDER BABIES, NSW 2000-2004"

Apgar score Year

$\begin{array}{lllll}\text { at } 5 \text { minutes } & 2000 & 2001 & 2002 & 2003\end{array}$

\begin{tabular}{|c|c|c|c|c|c|c|c|c|c|c|}
\hline & & & & & \\
\hline & No. & $\%$ & No. & $\%$ & No. & $\%$ & No. & $\%$ & No. & $\%$ \\
\hline $0-4$ & 41 & 1.9 & 49 & 2.3 & 38 & 1.7 & 42 & 1.9 & 34 & 1.5 \\
\hline $5-6$ & 26 & 1.2 & 29 & 1.4 & 31 & 1.4 & 30 & 1.4 & 34 & 1.5 \\
\hline $7+$ & 2045 & 96.4 & 2048 & 95.8 & 2104 & 96.4 & 2109 & 96.3 & 2256 & 96.7 \\
\hline Not stated & 10 & 0.5 & 12 & 0.6 & 10 & 0.5 & 9 & 0.4 & 9 & 0.4 \\
\hline TOTAL & 2122 & 100.0 & 2138 & 100.0 & 2183 & 100.0 & 2190 & 100.0 & 2333 & 100.0 \\
\hline
\end{tabular}

Source: NSW Midwives Data Collection (HOIST). Centre for Epidemiology and Research, NSW Department of Health.

\# Due to under-reporting of Aboriginality to the MDC, it is likely that the true numbers are about one and a half times higher than shown.

\section{Special care and neonatal intensive care}

In 2004, 19.6 per cent of Aboriginal and Torres Strait Islander babies were admitted to special care units and 4.8 per cent were admitted to neonatal intensive care units (Table 52). This compares with babies born to non-
Aborignal or Torres Strait Islander mothers, of whom 14.4 per cent were admitted to special care units and 2.8 per cent were admitted to neonatal intensive care units in 2004.

\section{TABLE 52}

ABORIGINAL AND TORRES STRAIT ISLANDER BABIES ADMITTED TO SPECIAL CARE AND NEONATAL INTENSIVE CARE UNITS, NSW 2000-2004"

\begin{tabular}{|c|c|c|c|c|c|c|c|c|c|c|}
\hline \multirow[t]{3}{*}{ Unit of admission } & \multicolumn{10}{|c|}{ Year } \\
\hline & \multicolumn{2}{|c|}{2000} & \multicolumn{2}{|c|}{2001} & \multicolumn{2}{|c|}{2002} & \multicolumn{2}{|c|}{2003} & \multicolumn{2}{|c|}{2004} \\
\hline & No. & $\%$ & No. & $\%$ & No. & $\%$ & No. & $\%$ & No. & $\%$ \\
\hline Special care unit & 405 & 19.1 & 442 & 20.7 & 431 & 19.7 & 450 & 20.5 & 457 & 19.6 \\
\hline Neonatal intensive care unit & 86 & 4.1 & 82 & 3.8 & 71 & 3.3 & 83 & 3.8 & 113 & 4.8 \\
\hline TOTAL & 2122 & 100.0 & 2138 & 100.0 & 2183 & 100.0 & 2190 & 100.0 & 2333 & 100.0 \\
\hline
\end{tabular}

Source: NSW Midwives Data Collection (HOIST). Centre for Epidemiology and Research, NSW Department of Health.

\# Due to under-reporting of Aboriginality to the MDC, it is likely that the true numbers are about one and a half times higher than shown.

\section{Perinatal mortality}

Since 2000, the perinatal mortality rate among Aboriginal and Torres Strait Islander babies has varied from 11.0 to 18.2 per 1,000 births (Table 53). The rate of 11.6 per 1,000 in 2004 is higher than the rate of 9.0 per 1,000 experienced by babies born to non-Aboriginal or Torres Strait Islander mothers.

\section{TABLE 53}

PERINATAL DEATHS AMONG ABORIGINAL AND TORRES STRAIT ISLANDER BABIES, NSW 2000-2004"

Perinatal deaths

\begin{tabular}{|c|c|c|c|c|c|c|c|c|c|c|}
\hline \multirow[t]{3}{*}{ Perinatal deaths } & \multicolumn{10}{|c|}{ Year } \\
\hline & & Rate/ & & Rate/ & & Bate/ & & Bate/ & & Batel \\
\hline & No. & 1,000 & No. & 1,000 & No. & 1,000 & No. & 1,000 & No. & 1,000 \\
\hline Stillbirth & 24 & 11.3 & 29 & 13.6 & 18 & 8.2 & 24 & 11.0 & 20 & 8.6 \\
\hline Neonatal death & 13 & 6.1 & 10 & 4.7 & 6 & 2.7 & 9 & 4.1 & 7 & 3.0 \\
\hline TOTAL & 37 & 17.4 & 39 & 18.2 & 24 & 11.0 & 33 & 15.1 & 27 & 11.6 \\
\hline
\end{tabular}

Source: NSW Midwives Data Collection (HOIST). Centre for Epidemiology and Research, NSW Department of Health.

\# Perinatal deaths include deaths reported to the MDC only. As the MDC form is completed at discharge or transfer of the baby, deaths occurring after this time may not be reported to the MDC. Due to under-reporting of Aboriginality to the MDC, it is likely that the true numbers are about one and a hal times higher than shown. 